\title{
“Durable Solutions," Transnationalism, and Homemaking among Croatian AND Bosnian Former Refugees
}

\author{
JASNA ČAPO
}

\begin{abstract}
This article proposes that the UNHCR-supported "durable solution" programs for former refugees from Bosnia and Herzegovina and from Croatia were at odds with the actual exilic experiences of former refugees. It introduces homemaking as an essential aspect of a successful durable solution and proposes supplementing the usual ethnopoliticized understandings of home in the specific context with analyses of the process of homemaking at different scales-house (dwelling), community (the wider space of settlement containing natural, cultural, social, and economic aspects) and nation. The article also argues that repatriation and local integration in the country of first asylum-two allegedly distinct and opposite solutions to refugee crises-should be viewed as intertwined processes within a broader transnational context. It is concluded that their combination brought a durable solution to refugee predicaments in the specific case.
\end{abstract}

\section{Résumé}

Cet article propose que les programmes de "solutions durables "soutenus par le HCR pour les anciens réfugiés originaires de la Bosnie-Herzégovine et de la Croatie ne s'accordaient pas aux expériences vécues de ces réfugiés. Il introduit la notion d'établissement de domicile comme un élément essentiel d'une solution qui puisse réussir et propose de supplémenter les conceptions ethnopoliticisées habituelles concernant l'idée d'un domicile que l'on trouve dans ce contexte particulier avec des analyses du processus d'établir un domicile sur des échelles variées, notamment celle du domicile en soi (lieu d'habitation), celle de la communauté plus large dans laquelle l'installation a lieu, contenant des éléments naturels, culturels, sociaux et économiques, et celle de la nation. L'article soutient aussi que le rapatriement et l'intégration locale dans le pays de premier asile, deux solutions aux crises de réfugiés qui ont été conçues comme distinctes et en opposition, devraient être considérées comme des processus complémentaires et interdépendants dans un contexte transnational plus général. Pour conclure, l'article avance que leur application simultanée avait apporté une solution durable à des problématiques de réfugiés dans le cas particulier dont il est question.

\section{Introduction}

C 7 he renovation of a house does not in itself make a home." This sentiment was shared by a young

Bosniac participant in a roundtable on homemaking and integration in post-Dayton Bosnia and Herzegovina, held in Sarajevo in March 2013 with representatives on all sides of the ethnic divide. The man, who had returned to the Serb Republic (Republika Srpska) described "a permanent feeling of insecurity" that prevents him from regaining the feeling of home in his hometown. His insecurity stems from the lack of Bosniac participation in the political process and administration of the Serb Republic, and the lack of memorialization of war crimes committed against the Bosniacs. 
Another man, himself a Serb who had stayed in Sarajevo during the Serbian siege, voiced a similar opinion and, at the same time, a grievance: the "four walls" of his house were not sufficient to generate a home-like feeling; like the Bosniac participant, he asserted that, in order to (re)integrate, one must feel at home in "the wider area," but the streets and neighbourhoods, now replete with the names of Bosniac historical heroes, are not conducive to such a feeling among the city's Serbian population.

These two speakers at the Sarajevo roundtable, although with different backgrounds, geographical origins in Bosnia and Herzegovina, and war experiences, equated home and home-like feeling not only with their immediate dwelling, but with wider scales of social and geographic space surrounding it. For them, home also extends from the street, neighbourhood, and local community to the encompassing political structure, the state, and, in particular, the nation. When speaking about home, they easily and naturally slipped from reference to the house as home to the idea of home as national homeland and claimed that they could not restore the feeling of security and familiarity-that is, the feeling of being at home-in an ethno-national polity where they are a minority. These examples voice an ethnonationalized and politicized idea of home, in which "home" becomes conflated with the national homeland. They exemplify the framework of thought that stresses the utmost relevance of ethno-nationality and ethno-politics for successful return and reintegration of refugees. That ethnicized discourse of home is common to most accounts dealing with the post-Yugoslav space in the context of "durable solutions" that UNHCR implemented in refugee crises in Bosnia and Herzegovina and Croatia. The article challenges this presumed link between an understanding of home as nation and the evaluation of the effects of durable solutions in the particular context, by arguing that a more encompassing notion of homemaking is needed to evaluate a durable solution as successful.

In the past twenty years, voluntary repatriation has been given precedence over two other durable solutions devised by UNHCR to manage refugees, namely, local integration in the country of asylum and resettlement to third countries. It has been privileged by both international stakeholders and national states. ${ }^{1}$ This has a political background related to the disappearance of the Cold War era but also a grounding in the "metaphysics of sedentarism." " In the post-Yugoslav context, repatriation had an additional rationale-it was aimed at reversing "ethnic unmixing" and recreating ethnically mixed areas as they existed in pre-war times. ${ }^{3}$ Most commonly, then, repatriation took the form of "minority return." The term is used to describe persons returning to areas not or no longer controlled by their ethno-national group. Stipulated as a prerequisite for post-conflict reconciliation, minority return was promoted by international aid agencies and foreign donors. Local integration-or settlement of refugees in the areas where they fled into exile (in this case, usually in the country in which their ethnicity was in the majority)—was, in contrast, minimally backed by these agencies, even while people engaged in it and some countries of exile encouraged it. I argue that both of these "solutions" resulted in a period of more or less protracted displacement and that neither brought a truly "durable solution" to the refugees' predicaments, because neither created the foundations necessary for the refugees to feel at home. Empirical data show that home was not more easily reconstructed within the scheme of local integration among refugees' co-nationals than in the place of origin within the scheme of refugee repatriation (in this context, minority return).

Furthermore, in this article I question the supposed mutual exclusivity of repatriation and local integration and critique the preference given to repatriation over local integration in the post-Yugoslav space. I argue that instead of dwelling on separate states' contexts and supposedly distinct solutions, international actors should have adopted a transnational approach to the management of refugees. This approach could have elucidated transmutations and combinations of repatriation and local integration across state borders. In addition, resettlement (secondary movements within the country of repatriation or to third countries) could have been employed as a third option for resolving the refugee crisis. Finally, I argue that, on the basis of empirical research, a combination of these two or three solutions, involving the countries of origin, exile, and third countries, seems to have been economically a most viable outcome of durable homemaking by refugees in the area.

In this respect, the article acknowledges and brings into the picture the transnational dimension of refugee mobilities. It gives support to Van Hear's thesis that formation of a transnational social field in refugee diaspora is an "enduring solution" to the condition of displacement. 4 The article thus combines forced migration (refugee) issues with insights provided by transnational migration studies. In the specific context that it scrutinizes, it relies on studies that have analyzed repatriation in the post-Yugoslav space as an "open-ended process" with transnational dimensions rather than a definitive closure of the refugee cycle..$^{5}$ I theorize open-endedness within the transnational framework of analysis. Researchers have conceptualized transnationalism in different ways, including a variety of phenomena under the notion. ${ }^{6}$ Relevant for this article is the understanding of transnationalism as the multiplicity of involvements that migrants sustain in two or more societies, thus creating 
"transnational social spaces" that go beyond geographic, political, and cultural boundaries. ${ }^{7}$ By their actions, decisions, concerns, and identifications within social networks that connect them to two or more societies simultaneously, migrants create a single arena of social action.

The article argues that in this context of dislocation and protracted refugee situations, people managed to create a sense of home in the trans-local and transnational space. I propose an understanding of refugee integration that captures the notion of home as constituted and negotiated, and not given and fixed, as a processual and evolving aspect of becoming emplaced in a new environment and not as essentialized and naturalized attachment to the house and/ or place/territory of origin. ${ }^{8}$ In this approach, then, home is analyzed as a practice (homemaking) that evolves. The analytical framework encompasses multiple scales of homemaking simultaneously-house (dwelling), community (town/village), nation. The scaling of home takes its cue from David Morley's argument that "the extent of space in which a person may feel at home varies-from the space of a house to that of a street, a neighborhood, whole country,"9 and Ulf Hannerz's distinction between homemaking at the level of dwelling, of town/village, and of the nation, polity, and/or society. ${ }^{10}$ Rather than assuming that home equals just a dwelling and that a successful/durable solution results from reclaiming the pre-war dwelling (as in minority return schemes) or that home is "naturally" regained by settling in the space controlled by one's nation (as in local integration among co-nationals and the examples quoted at the beginning of the article), my analysis tries to capture people's own meanings of home and how they resist and go beyond policy-driven and ethno-politicized understandings. Empirically, the intermediate scale of homemakinglocated between house and nation-appears to have been the most difficult to achieve. At the same time, an enduring home appears to have been created transnationally.

The article is an analysis of protracted refugee situations in Bosnia and Herzegovina and Croatia. Displacement contexts and solutions deployed in these Yugoslav successor states vary widely from the situation in other displacement contexts in Europe and beyond, insofar as in most instances of displacement, people sought refuge among their conationals in another state, i.e. in the country dominated by their national group. For example, Croats from Bosnia and Herzegovina and Serbia fled to Croatia, Serbs from Croatia fled to Serbia or to Serbian-dominated areas in Bosnia and Herzegovina, and Bosniacs relocated to Bosniac-dominated areas within Bosnia and Herzegovina. These displacements led either to minority return (repatriation) or to local integration in the country of asylum, which happens also to be the displaced persons' "national homeland." The regional specificity of displacements and, as a consequence, also of repatriation and local integration schemes warrants analysis. I contend that the evaluation of displacements and "durable solutions" across the state borders is a necessary transnational context, not only for understanding refugee agency in the area, but also for critically evaluating international solutions and understanding the protracted precarity of refugees' livelihoods.

Within the proposed framework, I aim to analyze a number of studies on displacement and "durable solutions" produced by other researchers of the area. My own research data about a case of local integration in the country of first asylum inform this analysis, directly or indirectly. It is based on ethnographic fieldwork I conducted among Croatian refugees from Serbia several years after they arrived in Croatia, in the mid-199os, and almost twenty years later, in the late 20oos. The first phase of research used participant observation and informal and formal meetings and interviews with mostly middle-aged and elderly refugees as well as with the local population among whom they settled in a locality in northern Croatia. ${ }^{11}$ The follow-up was done in 2009-11, by engaging with some of the same interview partners as ten or more years ago and by introducing some new ones, in Zagreb and elsewhere in Croatia. ${ }^{12}$

The article is divided as follows: after a brief presentation of the break-up of Yugoslavia and the rise of successor nation-states, I describe complex population displacements triggered by the wars in Croatia and Bosnia and Herzegovina as well as the controversies surrounding the two solutions to refugee crises: repatriation, which, in the form of minority return, was the focus of international actors such as UNHCR, and local integration in the country of first asylum (and also the "national homeland"), which was practised by refugees without international support. I then show how both solutions resulted in protracted displacement, since refugees developed ambivalent feelings of "home" under either scenario. This finding is used to critique ethnicized explanations of the alleged failure of minority returns. The next section discusses how refugees utilized repatriation and local integration schemes in order to arrive at viable solutions to their predicaments. On the basis of these insights, I critique the assumed exclusivity of repatriation and local integration in refugee management. In the final section, before a summary of findings, I pick up the argument that homemaking should not be evaluated in terms of ethno-politics only and discuss different scales at which home was created among former refugees.

\section{Background and Context}

The multinational Socialist Federative Republic of Yugoslavia (founded in 1943) was dismantled in 1992 following the 
wars that raged in the territories of its constituent republics, Croatia and Bosnia and Herzegovina. The duration of the wars extended well beyond the disappearance of the socialist Yugoslavia and the creation of independent successor states that emerged during the $1990{ }^{13}{ }^{13}$ In Croatia, the main brunt of fighting between the Croatian army and rebel Croatian Serbs, backed by the Yugoslav national army, was over in 1992. However, one-third of the Croatian territory was occupied by the Serbs and remained exempt from Croatian state control until 1995 and 1998. The war in multi-ethnic Bosnia and Herzegovina, which was at different periods fought in various constellations of the three main actors (Bosniacs, Croats, and Serbs), ended in 1995. The new state was consolidated by the Dayton Peace Agreement, which essentially institutionalized the ethnic divisions by dividing the country into two entities: Republika Srpska (the Serb Republic) and the Federation of Bosnia and Herzegovina. The first is dominated today by Serbs, the second by Bosniacs and Bosnian Croats.

The wars provoked unprecedented refugee crises that affected the wider region. Very briefly and without going into detail, I shall mention some of them. Following the occupation of its territories, Croatia had huge numbers of internally displaced persons as well as refugees from Bosnia and Herzegovina, both Croats and Bosniacs; after their liberation, internally displaced Croats could return to their homes, but Serbs fled from these same areas and found refuge in Bosnia and Herzegovina and Serbia. The war in Bosnia and Herzegovina produced much larger numbers of refugees and internally displaced persons among all three nations in the country: Bosniacs, Croats, and Serbs. Croats and Serbs went into exile in their nearby "national homelands" (Croatia and Serbia), but Bosniacs could either remain internally displaced or seek refuge in third countries (and on a temporary basis also in Croatia). With the cessation of enmities, refugees started coming back to their pre-war areas. The specific nature of the displacements and repatriations, and how they are linked to the decisions to remain in the country of first asylum, will be discussed on the following pages.

\section{Displacements and Their Controversial Reversal}

It is generally concluded that the displacement of "ethnic Others" was "a strategic parameter in the 1992-1995 war" in Bosnia and Herzegovina. ${ }^{14}$ Across Yugoslavia, people were forced into displacement by threats, the spread of fear, killings and similar deeds, because of being identified as a certain ethnic/national group. Many displacements were individual acts in search of security that eventually triggered displacement of entire villages and regions. Such was the case, according to my research, of the Croatian inhabitants of northern Serbia who relocated to Croatia. ${ }^{15}$ Nationalist elites sometimes orchestrated displacement and instrumentalized people for their nationalistic politics, as when they helped resettle Croats from Kosovo to Croatia, ${ }^{16}$ issued an order to the Serbian civilian population to leave their settlements and withdraw from Croatia together with the defeated Serbian rebel army, ${ }^{17}$ and called upon displaced Bosnian Croats to settle abandoned Serbian property in Croatia. ${ }^{18}$ In Bosnia and Herzegovina, the resettlement of Bosnian Croats into the western part of the country or, in the aftermath of the war, the induced exodus to territories under Serbian control by Bosnian Serbs from Sarajevo suburbs, ${ }^{19}$ also fall into this category.

As mentioned, the politics and ideology of repatriation have underlain efforts of international organizations and nation-states to encourage and mediate the return of refugees to their original homes in Bosnia and Herzegovina and Croatia, at the expense of implementing other solutions, including local integration and resettlement to third countries. Repatriation has meant mostly encouraging "minority return," i.e., repatriation to areas/states that were governed by another ethno-national group. Minority return has emerged as a moral argument, a political "righting of wrongs" committed by the displacement of "ethnic Others." Therefore, it was designed not only to reverse displacement, but to reverse ethnic homogenization as its consequence. Thus it became inseparable from the notions of post-conflict reconstruction, reconciliation, and peace process in the area. ${ }^{20}$ For the same reason, local integration in a place of exile-which implied durable settlement of displaced persons among their nationals-has been downplayed and rendered "taboo" by international stakeholders, because backing it would have sealed ethnic unmixing triggered by the war. ${ }^{21}$

Repatriation was to be ensured by property restitution, which was enshrined in the Annex 7 of the Dayton Peace Agreement and made obligatory for all signing parties in Bosnia and Herzegovina. ${ }^{22}$ Thus the right to return to the former war areas has not become just the right to return to the country of origin, but to return to the areas of origin via restitution of abandoned, and in the meantime also partly or entirely destroyed, property. Similar institutional provisions were made in Croatia, though much later. ${ }^{23}$

The scale of minority returns in Croatia and Bosnia and Herzegovina, measured by the figures of returned property, was impressive-nearly half a million minority returns in Bosnia and Herzegovina, and about 130,000 minority returns in Croatia. ${ }^{24}$ These figures are ostensibly grounds for the international community to positively evaluate their achievements. ${ }^{25}$ However, these statistics need some qualification. Researchers have pointed out that only about 38 per cent of registered minority returnees reside permanently in Croatia. ${ }^{26}$ In the Serb Republic, that number hovered around 
42 per cent in $2003 .{ }^{27}$ Clearly, property restitution, which to this day has been almost fully effected in both countries, was not followed by the return of people, and therefore cannot be used as a proxy for the number of returnees and the "success" of minority return schemes.

Rather than returning definitively, people have engaged in degrees of return, ranging from occasional stays overnight to permanent return. Stef Jansen, who has systematically been unravelling the unexpected outcomes of repatriation schemes in Bosnia and Herzegovina for more than a decade, ${ }^{28}$ has discovered other interesting facts hidden behind the statistics: that half of Bosniac repatriates were actually "majority repatriates," and that many Bosniac returnees (who would have become minority returnees had they indeed returned to their homes of origin after reclaiming property, as expected by the Dayton Peace Agreement) ended up relocating within Bosnia and Herzegovina in order to settle among their nationals. ${ }^{29}$ In other words, what was organized as a minority return ended up in secondary migration within Bosnia and Herzegovina and became "majority return."

Thus, instead of reversing one of the consequences of the war-ethnic unmixing-repatriation schemes inadvertently produced largely the opposite effect of what was expected and confirmed ethnic homogenization in Bosnia and Herzegovina, and less so in Croatia. It is ironic-and at the same time hypocritical-that the Dayton Peace Agreement, enforced by international actors on Bosnia and Herzegovina, institutionally legitimized military conquests and ethnic divisions by partitioning the country into two constituent entities based on the control of the dominant ethno-national group. This process ran parallel to efforts of the very same international actors to reverse the effects of ethnic unmixing by prioritizing minority return and ignoring local integration..$^{\circ}$ The consequence of this "schizophrenic" situation ${ }^{31}$ was that political structures in Bosnia and Herzegovina-as well as in Croatia several years after the war-were opposing minority return and stimulating local integration; i.e., they were acting in exactly the reverse of international efforts.

Even though it was left out of international consideration as a "durable solution," local integration in the areas of exile-which implied settling among co-nationals-was widespread. In spite of international directives and money put towards minority return, local processes in Bosnia and Herzegovina and Croatia were actively consolidating ethnically unmixed areas. As already mentioned, this was achieved in Bosnia and Herzegovina by majority returnees but also by those minority returnees, who, after having reclaimed their property in the pre-war locations, remigrated to the entity governed by their national majority.
Croatia, which witnessed significant minority returns of exiled Serbs, was also the arena of exile and integration of a large number of Croats from Bosnia and Herzegovina (who subsequently also reclaimed their property in Bosnia and Herzegovina) as well as some numerically smaller Croatian groups from Serbia. In other words, ethnic homogenization in post-Yugoslav successor states was strengthened as a result of several local processes and defiance of international political and policy decisions: remaining in the country of first asylum, majority return and minority return followed by secondary displacement.

Both returnees and those who chose local integration in the country of first asylum had difficulties in making a home, the first in the areas of origin, the second in their alleged national homeland. The next section sets out the experiences of home among refugees in both situations.

\section{Experiences of "Home"}

Studies of returnee experiences in Bosnia and Herzegovina have deconstructed and de-essentialized the idea of "home," as the original place of "natural" belonging to which one has to return to retrieve the feeling of being "at home." Researchers speak of negotiations of home rather than of natural reinsertion in the society; ${ }^{32}$ of ambivalent homecomings; 33 of hesitant returnees ${ }^{34}$ and they challenge the idea that returnees can experience their homes of origin as "homes" in the light of their radical transformations. 35

In one way or another, researchers have called for a need to consider broader socio-political aspects in securing and evaluating the "success" of return processes in the area. They have analyzed belonging and attachment to places as contingent on wider social and historical processes through which people "lay claim to a place and call it home." 36 Jansen and Löfving 37 have underlined the necessity of understanding the context of economic and political transformations as they intersect with changes in individual and social trajectories of refugees..$^{8}$ Stefansson has criticized the "de-politicized" understanding of homes by international agencies and policy-makers - that is, their idea that a person just needs to be given his house back in order to reestablish himself at "home"-and has argued that the project of property restitution enshrined in the Dayton Peace Agreement was unsuccessful because it was reduced to "small home politics" at the expense of taking into account the wider context of return, or "big home politics." 39 The author claimed that a "full sense of home" can be recreated only when there develops a "positive connection between the house - the 'small home' and 'its social surroundings'or the 'big home."'40

These arguments reiterate the opinion voiced by the participants in the roundtable mentioned at the beginning of 
the article. However, I challenge this ethnicized explanation of minority returnees' failure to regain home. If it were valid, should we not assume that the home was more easily constructed under the scheme of local integration in the country of asylum, for the reason that refugees integrated among their nationals, in their "big home"?

The answer to that question is not straightforward. My research into the integration of Croats from Serbia in Croatia confirms this. The integration of Bosnian Croats in Croatia and that of the Serbs in the Serb Republic offer equally illuminating case studies of the problem. Bosnian Croats fled their pre-war homes in Bosnia between 1992 and 1996 and chose Croatia, their presumed "ethnic homeland" as the country of exile, in which the majority stayed, even after having repossessed their property in the abandoned localities of origin in Bosnia and Herzegovina in the 200os. They were given Croatian citizenship soon upon arrival, which paved the way for their local integration, but at the same time excluded them from international aid, since with the conferral of citizenship they fell out of the category of "refugee." However, their lives continued in limbo for years to come.

Unfortunate decisions by the Croatian state contributed to their dilemna. It allowed them to settle in the exiled Serbs' private property, ${ }^{41}$ that Bosnian Croats, themselves destitute displaced persons, did not hesitate to occupy. This turned them from victims into a sort of war profiteers, which isolated them even further from international aid but also from the local population. The density of their settlement and their occupation of Serbian property not only earned them negative attitudes from the returnee Serbian populationwhich was forced to wait for the Bosnian Croats to vacate their houses-but also from the local Croatian population who, in addition, resented their alleged resourcefulness and privileges given by the state. ${ }^{2}$ They encountered exclusion from the locals precisely when they were in a difficult situation of protracted waiting for a solution to their housing problem. Their housing uncertainty lasted some five to seven years after settlement and supposed "local integration" in Croatia. ${ }^{43}$ Also, they were negatively stereotyped by the local Croats as a "less civilized" people arriving from Bosnia, especially if they were coming from lower socioeconomic circumstances and less educated backgrounds. 44 Insecure housing, non-existent jobs in the marginal areas of settlement, failure to be recognized by the locals as the we group, etc., all contributed to liminality in which they lived for years without developing a feeling of belonging and home.

The difficulties encountered by Bosnian Croats in Croatia have been similar to those of Serbs who, after repatriating in the Federation of Bosnia and Herzegovina, embarked on a second migration to the other entity, the Serb Republic. When they are compared to minority Bosniac returnees in the Serb Republic, it appears that it might well be the Serbian secondary migrants who were in a more precarious socio-economic situation and encountered more hurdles in the process of integration in the Serb Republic than the minority Bosniac returnees. ${ }^{45}$ This is a bold and unexpected statement, especially when viewed from the dominant perspective of ethnicized explanations of refugee solutions in the former Yugoslav space.

On the basis of these insights, I contend that the settlement among one's own national group does not decisively ease homemaking and the integration of refugees in the receiving society. Very much like minority returnees, they do not integrate unambivalently in their new settlements, in spite of the fact that their settlement occurs in their "national homeland." 46 While minority returnees cannot simply regain lost homes because they come back to what are radically transformed surroundings (destroyed property, economic problems, changes in politics, etc.), those integrating in the country of asylum, even though it is controlled by their nationals, have come to completely new surroundings, in which their predicaments might be worse than those of returnees. Both share, in one way or another, an experience that can better be described as that of an immigrant rather than a "naturalized" returnee (due to the recovery of "original" home) or ethnic settler (due to the recovery of "national homeland") experience. 47 If we are to understand the most important dimensions of home and homemaking in the process of attaining a successful durable solution, we need to look at economic viability as the main feature of durability and take into account different scales at which refugees experienced homemaking: house, community, nation. The two following sections discuss this point.

\section{Ensuring Viable Livelihoods}

As has been mentioned, repatriation in many cases set in motion a second displacement within Bosnia and Herzegovina. This did not mean that displaced persons, who became minority returnees and later resettled internally, severed bonds with any of the places in which they lived at some point. In simpler scenarios, a Serb refugee returning to Croatia did not severe ties with the settlement of exile in Serbia and a Bosnian Croat integrated in Croatia but also reclaimed property in the pre-war place in Bosnia and Herzegovina. In all cases, contacts between these places was kept on a regular or irregular basis. These forms of "open-ended return" led to trans-local (within Bosnia and Herzegovina) ${ }^{48}$ and transnational (across international borders) families and economies and to circular migration between the areas.

These developments challenge established understandings of "durable solutions" to refugee crises, as distinct and 
mutually exclusive forms. They point out that the boundary between return and local integration can be fluid, and that even with the firm intention and orchestrated international political and donors' support, as well as monitored direction of funding, repatriation can transmute into or be combined with local integration in country of first asylum. They can be complementary and interdependent processes: in order to be able to enact a second migration within Bosnia and Herzegovina, a person had first to secure property restitution in the area of origin via minority return schemes, and then, with its sale or exchange, could ensure housing elsewhere, in the entity controlled by her or his ethnic group. This is exactly what Croatian refugees from Serbia were doing in the first place: when as an ethnic minority they felt threatened in Serbia and decided to leave, they managed their local integration in the country of asylum by negotiating property exchange with the Serbian population in Croatia. ${ }^{49}$ It took Bosniac and Serbian refugees in Bosnia and Herzegovina several years, maybe even a decade, to achieve the same result. In other words, they spent a protracted period of insecurity and liminality until they could ensure some stability for their families and themselves. While the above scenario is specific to the area under analysis, the one in which repatriation is combined with local integration and possibly also with resettlement to third countries is more common and attuned to the contemporary transnational moment..$^{\circ}$

I argue that such transnational/trans-local arrangements were a strategy deployed by refugees to ensure sustainable livelihoods. ${ }^{51}$ They have spent protracted periods-ten or more years-in insecure and unresolved liminal situations, waiting for the involved states and international actors to agree on a common solution to their plight, sometimes waiting for their houses to be vacated or rebuilt, competing for meagre resources with the locals, lacking local social networks, and struggling to ensure viable livelihoods and future for their family members and themselves. Living in the place of exile or in the place of return was not bringing satisfactory livelihoods and durable homemaking for all these reasons. Linking these two places into a common social space did bring a solution. What helped the integration of Bosnian Croats in Croatia were not only closely knit social networks in areas of compact settlement of extended families and neighbours from the pre-war villages, but also transnational social spaces established with elderly relatives who returned to their Bosnian settlements and possibly also with the younger ones who migrated to third countries in search of (seasonal) work (e.g., in Germany). A combination of two or even three "solutions" made their settlement in under-developed Croatian regions viable. As it is with the minority returnees who relocate but whose livelihoods straddle the interior border in Bosnia and Herzegovina, ${ }^{52}$ it is difficult to ascertain where the Bosnian Croats actually live: they are registered in and have documents of both Croatia and Bosnia and Herzegovina, they have two homes in two states and might live alternatively in one or the other (or maybe even in a third one) for indefinite, prolonged periods of time, depending on job opportunities in these places, while they take advantage of welfare benefits in both countries.53

By keeping ties with the areas of former exile or return, refugees have been keeping options open, spreading out risk factors, and creating a strategy to minimize exposure to the precariousness of life in post-war Bosnia and Herzegovina and Croatia. By stressing future-orientated projects of returnees and the need to create economically sustainable livelihoods "beyond considerations of nationality," Jansen has argued for an understanding of returnees' decisions to relocate that goes beyond the ethnic/national lens. ${ }^{54}$ The notion of "normalcy" contains the same type of reasoning: rather than exclusively preoccupied by ethnic considerations (and fears of the "ethnic Other"), people strive to ensure good living and normalcy,55 and do not dwell on romantic or ideologized notions of national home. Similarly, as minority Serbian returnees and locals start working together and sharing the problems of infrastructural deficiencies in the marginal areas of common settlement in Croatia, ethnicity takes on a secondary role in everyday communication. ${ }^{56}$ Ethnicity and an ideologized notion of home as nation may still be evoked in public roundtables, as in the quotes at the beginning of the article. I argue that such ethno-politicized statements reflect dominant discourses rather than empirical situations of everyday life.

It follows from my analysis that refugees, no matter how their refugee trajectory evolved, engage in very similar activities, which take them beyond the ethnic and into the realm of economic reasoning that is managed in trans-local and transnational space. In the final section of the article, I explore aspects of homemaking in this context.

\section{Scaling Home: Levels of Homemaking}

In the cases presented, the deceptive nature of "home" for refugees has appeared in two ways: on the one hand, in the context of the recovery of pre-war houses by minority returnees and, on the other, in the context of local integration in presumed "national homelands." In the first case, except for elderly people,57 pre-war dwellings could not be refilled with the meaning of home, as the naturalizing sedentarist discourse would expect. While some explanations attribute this to drastic transformations in the pre-war areas of settlement,,$^{58}$ many more invoke the disjointed relationship of a minority returnee with the national majority 
in the area. These interpretations prioritize an understanding of home in terms of a national homeland. After finding that, in the context of local integration among co-nationals, the ethnicized argument appeared to be without foundation, I have challenged ethnicized explanations of failed homemaking in minority repatriation schemes. That argument is strengthened in this section by pointing out different meanings of home and levels of homemaking among a group of Croatian refugees from Serbia that I studied.59 The analytical framework I used looked at homemaking at the level of house (dwelling), community (town/village), and nation.

I found that exchanged houses were made into homes slowly and over a period of time, after refugees had imbued them with meaning. Immediately after arriving, the refugees did not consider them "theirs." But after fifteen or more years, the house became meaningful as the site of material input, investment of efforts and activities, of the implementation of ideas and projects. In that second period of my research, it was also presented as a site of family togetherness, familiarity, and security. The community (town or village), which embraces a natural (landscape), cultural (built environment, symbolic meanings, gestures) and social (networks) aspect of belonging, generated less home-like feelings among my research subjects. While the feeling of "home" in Serbia was a holistic experience embracing the entire broader area of the place of living, in Croatia, people continued to experience the physical and social environment in which they lived as not entirely "their own." This was reiterated almost twenty years after the displacement. Their social networks are oriented toward socializing among other settlers like themselves, their former co-villagers, who live in the same or other localities in Croatia. By socializing among themselves-rather than with the locals among whom they livethey recreate, trans-locally and transnationally, the social and cultural space of the old settlement, by which a sense of belonging to the old village as "the home" is imagined and enacted outside its territory. ${ }^{60}$ I therefore hypothesize that their relationship with the places in which they reside today, almost twenty years after displacement and the onset of local integration, is merely functional. They are simply housing locations, while only the relation towards the house and property is emotional. ${ }^{61} \mathrm{With}$ the passage of time, these refugees who integrated in the country of asylum (which also happens to be their national homeland) thus managed to imbue their new houses with the meaning of home, but have not managed to imbue the surrounding area with the same meaning.

At this intermediate level of homemaking, I suggest, we need to consider economic viability. The assertion by a Turkish migrant working in Germany that "home is wherever you have a job"62 seems to be equally valid in this post-refugee context. It resonates with the statement of a man who participated in the Sarajevo roundtable mentioned above: "My home was destroyed when I was thrown out of my job." This is maybe the most concrete but also the most poignant definition of home that I have encountered. It lends support to a further argument, that settlement in the country of first asylum (and also secondary migration to the territory inhabited by co-nationals) can also be viewed as a search for sustainability and not only as ethnically motivated mobility. This does not deny that there was not an initial ethnic motivation for displacement. It was indeed present under conditions of heightened war and the early post-war situation. My research elucidates that at the beginning of displacement, the refugees were indeed mentioning the importance of being "among their own" as a factor contributing to their homemaking. In later phases, however, this was no longer an issue. Therefore, I reiterate the argument that in order to understand the different facets of the process of homemaking in the particular refugee experiences, we need to move beyond ethnic/national reasoning and consider durable homemaking as a process linked to a concatenation of factors such as becoming emplaced in the house, social networks, and economically viable trans-local and transnational contexts. Only in the last resort, and in a short period after the conflict that had caused displacement, is the ethno-political context important for homemaking. It is further argued that the intermediary level of homemaking is a vital element in the development of attachment and the feeling of home. It is the most difficult of scales to achieve; it is the missing but necessary link between the concreteness of the house as home and the abstract, third level-the understanding of home as the nation, polity, and/or society.

\section{Concluding Remarks}

The article focuses on tensions produced by ethno-national politics (which caused unprecedented population displacements of "ethnic Others" in the former Yugoslav space, especially in Croatia and Bosnia and Herzegovina), international agendas (which, by privileging minority return as the "durable solution," engaged in the politics of redressing the wrongs of ethnic unmixing), and finally and most importantly, refugees' own understandings of and attempts to find durable solutions for the protracted precarity in which they found themselves.

I have introduced homemaking as an essential aspect of a successful durable solution and have proposed supplementing the usual ethno-politicized understandings of home in the specific context with analyses of the process of homemaking at different scales - the house (dwelling space), community (the wider space of settlement containing natural, cultural, social, and economic aspects), and nation. 
The first two are the spaces of lived, everyday, unmediated experiences of the familiar and self-evident, ${ }^{63}$ the spaces in which a person is recognized and acknowledged by others, and also the spaces in which people feel economically secure and can forge future plans. I have underlined the difficulties of homemaking at the intermediate level and the importance of the economic aspect, both of which are missing from most analysis of homemaking. The analysis has shown that, in pursuing economic viability, refugees reach beyond immediate places of settlement into trans-local and transnational space. I have argued that transmigration between their places of origin and exile and the creation of transnational social fields was their own solution to protracted insecurities of homemaking.

Furthermore, my analysis of Bosnian-Herzegovinian and Croatian refugee mobilities has questioned the sustainability of the strict distinction between return and local integration employed by UNHCR. Of these two, the first, via an international political consent, was given precedence over the second, with the result that the "real necessities" of the displaced who chose local integration in the country of first asylum rather than return were neglected by international and sometimes also national politics and policy-makers. In other words, politics enmeshed itself in humanitarian matters and brought about prolonged vulnerability to some displaced people while trying to help others. Paradoxically, even those targeted were not exempt from long periods of insecurity under refugee status. The combined effect of international and local national politics in the region thus resulted in protracted precarious circumstances for displaced people that have required more and more financial input and new programs to make up for inadequate decisions by international and national stakeholders.

I have argued that instead of privileging one solution-return/repatriation, especially in the form of minority return-and keeping it distinct from the widespread practice of local integration in the country of first asylum, international actors should have adopted a non-compartmentalized and transnational approach to the management of the multiple regional refugee crises, pursuing simultaneous return and local integration in the country of exile. This argument takes its cue from the empirical finding that repatriation and local integration in exile were closely intertwined processes in the specific regional context. They were combined by the refugees in order to secure durable solutions for themselves and their families. Transnational practices and lives straddling two or more places in different countries continue to be crucial for securing sustainable livelihoods. With the deepening of the economic crisis, transnationalism is further pursued and involves frequent secondary migration to third countries. This analysis then also shows how viability in a post-refugee context is an enduring search in unpredictable directions. ${ }^{64}$

Jasna Čapo is a senior research associate at the Institute of Ethnology and Folklore Research and titular professor at the University in Zagreb. She was a Humboldt fellow in Munich and Berlin. Her research interests are in the anthropology of forced and labour migrations and diasporic identities. Her books include Strangers Either Way: The Lives of Croatian Refugees in Their New Home (2007 and 2011) and the coedited volume Co-Ethnic Migrations Compared: Central and Eastern European Contexts (2010). The author may be contacted at capo@ief.hr.

\section{Notes}

1 B. S. Chimni, "From Resettlement to Involuntary Repatriation: Towards a Critical History of Durable Solutions to Refugee Problems," Working Paper 2 (UNHCR Centre for Documentation and Research, 1999); Richard Black and Saskia Gent, "Sustainable Return in Post-Conflict Context," International Migration 44, no. 3 (2006): 15-38.

2 Chimni, "From Resettlement to Involuntary Repatriation”; Liisa H. Malkki, "National Geographic: The Rooting of Peoples and the Territorialization of National Identity among Scholars and Refugees," Cultural Anthropology 7 , no. 1 (1992): 24-44; Malkki, "Refugees and Exile: From 'Refugee Studies' to the National Order of Things," Annual Review of Anthropology 24 (1995): 495-523.

3 Black and Saskia, "Sustainable Return"; Richard Black, Marita Eastmond, and Saskia Gent, "Introduction: Sustainable Return in the Balkans," International Migration 44, no. 3 (2006): 1-13; Marita Eastmond, "Introduction: Reconciliation, Reconstruction, and Everyday Life in War-torn Societies," Focaal: Journal of Global and Historical Anthropology 57 (2010): 3-16.

4 Nicholas Van Hear, "Refugees in Diaspora: From Durable Solutions to Transnational Relations," Refuge 23, no. 1 (2006): 9-13.

5 Marita Eastmond, "Transnational Returns and Reconstruction in Post-war Bosnia and Herzegovina," International Migration 44, no. 3 (2006): 141-66; Anders H. Stefansson, "Homes in the Making: Property Restitution, Refugee Return, and Senses of Belonging in a Post-war Bosnian Town," International Migration 44, no. 3 (2006): 115-39; Carolin Leutloff-Grandits, "Ethnic Unmixing in the Aftermath of the Yugoslav Successor Wars: The Integration of Co-Nationals in Former Yugoslavia in Comparative Perspective," in Co-ethnic Migrations Compared: Central and Eastern European Contexts, ed. Jasna Čapo Žmegač, Christian Voß, and Klaus Roth, 139-63 (Munich: Sagner Verlag, 2010); Milan Mesić and Dragan Bagić, Minority Return in Croatia: Study of an Open Process 
(Zagreb: UNHCR, 2011); Stef Jansen, "Refuchess: Locating Bosniac Repatriates after the War in Bosnia-Herzegovina," Population, Space and Place 17 (2011): 140-52.

6 Among others, Nina Glick Schiller, Linda Basch, and Cristina Blanc-Szanton, eds., Towards a Transnational Perspective on Migration: Race, Ethnicity, and Nationalism Reconsidered (New York: New York Academy of Sciences, 1992); Luis Eduardo Guranizo and Michael Peter Smith, "The Locations of Transnationalism," in Transnationalism from Below, ed. Michael Peter Smith and Luis Eduardo Guarnizo, 3-34 (New Brunswick, NJ: Transaction Publishers, 1998); Steven Vertovec, "Conceiving and Researching Transnationalism," Ethnic and Racial Studies 22, no. 2 (1999): 447-62; Thomas Faist, International Migration and Transnational Social Spaces (Oxford: Oxford University Press, 2000).

7 Glick Schiller, Basch, and Blanc-Szanton, Towards a Transnational Perspective; Linda Basch, Nina Glick Schiller, and Cristina Szanton Blanc, Nations Unbound: Transnational Projects, Postcolonial Predicaments, and Deterritorialized Nation-States (Basel: Gordon and Breach Publishers, 1994). 8 Akhil Gupta and James Ferguson. "Beyond 'Culture': Space, Identity, and the Politics of Difference," Cultural Anthropology 7, no. 1 (1992): 6-23; Malkki, "National Geographic”; Laura Hammond, “Tigrayan Returnees' Notions of Home: Five Variations on a Theme," in Homecomings: Unsettling Paths of Return, ed. Fran Markowitz and Anders H. Stefansson, 36-53 (Lanham, MD: Lexington Books, 2004); Maja Korac, Remaking Home: Reconstructing Life, Place and Identity in Rome and Amsterdam (New York: Berghahn Books, 2009); Shelley Mallett, "Understanding Home: A Critical Review of the Literature," Sociological Review 52, no. 1 (2004): 62-89.

9 David Morley, Home Territories: Media, Mobility and Identity (London: Routledge, 200o), 48.

10 Ulf Hannerz, "The Local and the Global: Continuity and Change," in Transnational Connections: Culture, People, Places, ed. Ulf Hannerz, 17-29 (London: Routledge, 1996).

11 Jasna Čapo Žmegač, Strangers Either Way: The Lives of Croatian Refugees in Their New Home (New York: Berghahn Books, 2007).

12 Jasna Čapo Žmegač, "Refugees, Co-Ethnic Migrants, and Diasporas: Blurring the Categories," in Čapo Žmegač, Voß, and Roth, Co-Ethnic Migrations Compared, 177-94.

13 At the beginning of the twenty-first century, Yugoslavia disappeared completely from the maps and was replaced by seven states: Slovenia, Croatia, Bosnia and Herzegovina, Serbia, Montenegro, and the former Yugoslav Republic of Macedonia and Kosovo.

14 Jansen, "Refuchess," 140.

15 Čapo Žmegač, Strangers Either Way.

16 Ger Duijzings, "Egzodus iz Letnice: hrvatske izbjeglice s Kosova u zapadnoj Slavoniji. Kronika," Narodna umjetnost 32, no. 2 (1995): 129-52.
17 Vjeran Pavlaković, "Fulfilling the Thousand-Year-Old Dream: Strategies of Symbolic Nation-Building in Croatia," in Strategies of Symbolic Nation-Building in South Eastern Europe, ed. Pal Kolsto, 19-49 (Farnham, UK: Ashgate, 2014).

18 Brad K. Blitz, "Refugee Returns, Civic Differentiation and Minority Rights in Croatia 1991-2004," Journal of Refugee Studies 18, no. 3 (2005): 362-86.

19 Jansen, "Refuchess."

20 Black and Gent, "Sustainable Return."

21 Phuong in Stefansson, "Homes in the Making."

22 Black and Gent, "Sustainable Return," 23.

23 Blitz, "Refugee Returns." Of course, the aim of return politics was also to increase human capital in demographically depleted areas of war and, as judged by Brad Blitz (lecture in Sarajevo, March 2013), in more cynical accounts, it was to relieve the burden on other states and justify international aid programs. See also Black and Gent, "Sustainable Return.”

24 UNHCR Representation in Bosnia and Herzegovina, Statistics Package, 31 December 2012, http://unhcr.ba/ wp-content/uploads/2013/o4/SP_12_2012.pdf; Mesić and Bagić, Minority Return in Croatia, 77.

25 Black, Eastmond, and Gent, "Introduction"; Jansen, "Refuchess."

26 Mesić and Bagić, Minority Return in Croatia, 82; estimate based on a sample.

27 Jagoda Petrović, Ničiji ljudi (Beograd: Socijalna misao, 2007).

28 Stef Jansen, “The Privatisation of Home and Hope: Return, Reforms and the Foreign Intervention in Bosnia-Herzegovina," Dialectical Anthropology 30 (2006): 177-99; Jansen, "Troubled Locations: Return, the Life Course, and Transformations of 'Home' in Bosnia-Herzegovina," Focaal: European Journal of Anthropology 49 (2007): 15-30; Jansen, "Refuchess."

29 Jansen, "Refuchess."

30 Stefansson, "Homes in the Making"; Eastmond, "Introduction."

31 Stefansson, "Homes in the Making."

32 Anders H. Stefansson, "Sarajevo Suffering: Homecoming and the Hierarchy of Homeland Hardship," in Homecomings: Unsettling Paths of Return, ed. Fran Markowitz and Anders H. Stefansson, 54-75 (Lanham, MD: Lexington Books, 2004).

33 Ibid.; Jansen, "Troubled Locations."

34 Laura Huttunen, "The Notion of Home for a Hesitant Bosnian Diaspora in Finland," in Feminisms in a Transnational Perspective: Rethinking North and South in Post-Coloniality, ed. Renata Jambrešić Kirin and Sandra Prlenda, 96-113 (Zagreb: Institut za etnologiju i folkloristiku and Centar za ženske studije, 2008).

35 Jansen, "Refuchess"; Petrović, Ničiji ljudi.

36 Eastmond, "Introduction," 9. 
37 Stef Jansen and Staffan Löfving, "Introduction: Movement, Violence, and the Making of Home," Focaal: European Journal of Anthropology 49 (2007): 3-14.

38 See also Jansen, "Troubled Locations."

39 Stefansson, "Homes in the Making."

40 Ibid.; Anders H. Stefansson, "Travelling States: State Reconfiguration, Co-Ethnic Migration and Non-Diasporic Identities in Bosnia's Republika Srpska," in Čapo Žmegač, Voß, and Roth, Co-Ethnic Migrations Compared, $165-75$.

41 Blitz, "Refugee Returns."

42 Carolin Leutloff-Grandits, Claiming Ownership in Postwar Croatia: The Dynamics of Property Relations and Ethnic Conflict in the Knin Region (Münster: Lit., 2006); Marko Valenta, Milan Mesić, and Zan Strabac, "Bosnian Croats in Croatia: 'Ethnically Privileged Migrants,' 'Culturally Distant Co-Ethnics' or 'Croats as Any Other Croats'?" in Bosnian Diaspora: Integration in Transnational Communities, ed. Marko Valenta and Sabrina Ramet, 281-30o (Farnham, UK: Ashgate, 2010).

43 Leutloff-Grandits, Claiming Ownership in Post-war Croatia; Carolin Leutloff-Grandits, "Croatia's Serbs Ten Years after the End of the War," Croatia since Independence: War, Politics, Society, Foreign Relations, ed. Sabrina P. Ramet, Konrad Clewing, and Reneo Lukić, 141-67 (Munich: R. Oldenbourg, 2008); Leutloff-Grandits, "Ethnic Unmixing."

44 Valenta, Mesić, and Strabac, "Bosnian Croats in Croatia."

45 Petrović, Ničiji ljudi.

46 The presumed "ethnic privilege" of the co-ethnically resettled population plays a role only at the beginning of their relocation (i.e., they are given citizenship); see Jasna Čapo Žmegač, "Ethnically Privileged Migrants in Their New Homeland," Journal of Refugee Studies 18, no. 2 (2005): 199-215.

47 Jasna Čapo Žmegač, "Return Migration: The Changing Faces and Challenging Facets of a Field of Study," Ethnologia Balkanica 14 (2010): 227-45.

48 Strictly speaking, this is not a transnational arrangement, for it straddles the interior entity border in Bosnia and Herzegovina (IEBL), when people live a life connecting a place in the Serb Republic and one in the Federation of Bosnia and Herzegovina.
49 Čapo Žmegač, Strangers Either Way.

50 Van Hear, "Refugees in Diaspora."

51 That refugees were taking things into their own hands and acting against official schemes is also shown by the fact that the peak of minority returns in Croatia was registered already in 1998 and 1999, as if in defiance of domestic opposition and economically dire situation in the postwar areas into which returnees came.

52 Jansen, "Refuchess."

53 Valenta, Mesić, and Strabac, "Bosnian Croats in Croatia." 54 Jansen, "Refuchess."

55 Anders H. Stefansson, "Refugee Returns to Sarajevo and Their Challenge to Contemporary Narratives," in Coming Home? Refugees, Migrants, and Those Who Stayed Behind, ed. Lynellyn D. Long and Ellen Oxfeld, 170-86 (Philadelphia: University of Pennsylvania Press, 2004); Jansen, "Troubled Locations."

56 Mesić and Bagić, Minority Return in Croatia.

57 Jansen, "Troubled Locations."

58 Ibid.; Jansen, "Refuchess."

59 They were less exposed to protracted precarity than other refugees, because they immediately became Croatian citizens, and they secured their livelihoods by exchanging houses and land with Croatian Serbs. Nevertheless, homemaking was not a self-evident and easy process; see Čapo Žmegač, Strangers Either Way; Čapo Žmegač, "Refugees, Co-ethnic Migrants, and Diasporas."

6o Čapo Žmegač, "Return Migration"; Huttunen, "The Notion of Home"; Hariz Halilovich, "Trans-Local Communities in the Age of Transnationalism: Bosnians in Diaspora," International Migration 50, no. 1 (2012): 162-78.

61 Valentina Gulin Zrnić, Kvartovska spika: Značenja grada i urbani lokalizmi u Novom Zagrebu (Zagreb: Institut za etnologiju i folkloristiku and Jesenski i Turk, 2009). This is certainly contributed to by the fact that they are middleaged and older; in other words, they did not attain their formative experiences in the places in which they are now living, but rather settled in them as mature adults.

62 Morley, Home Territories, 44.

63 Ibid., 48; Hannerz, "The Local and the Global."

64 I thank Stef Jansen, Cathrine Brun, Anita Fabos and two anonymous reviewers for valuable comments on the text. 
(C) Jasna Čapo, 2015. This open-access work is licensed under a Creative Commons Attribution-NonCommercial 4.0 International License, which permits use, reproduction and distribution in any medium for non-commercial purposes, provided the original author(s) are credited and the original publication in Refuge: Canada's Journal on Refugees is cited. 